九州大学学術情報リポジトリ

Kyushu University Institutional Repository

\title{
A novel hybrid MCDM approach followed by fuzzy DEMATEL-ANP-TOPSIS to evaluate Low Carbon Suppliers
}

Gupta, Vivek

Sant Longowal Institute of Engineering \& Technology

Jayant, Arvind

Sant Longowal Institute of Engineering \& Technology

https://doi.org/10.5109/4491640

出版情報：Evergreen. 8 (3)，pp.544-555，2021-09. 九州大学グリーンテクノロジー研究教育センター バージョン：

権利関係 : 


\title{
A novel hybrid MCDM approach followed by fuzzy DEMATEL-ANP-TOPSIS to evaluate Low Carbon Suppliers
}

\author{
Vivek Gupta ${ }^{1}$, Arvind Jayant ${ }^{2, *}$ \\ ${ }^{1}$ Sant Longowal Institute of Engineering \& Technology, Sangrur, Punjab, India \\ ${ }^{2}$ Sant Longowal Institute of Engineering \& Technology, Sangrur, Punjab, India \\ *Author to whom correspondence should be addressed: \\ E-mail: vivekgups@gmail.com
}

(Received July 26, 2020; Revised 28 May, 2021; accepted July 25, 2021).

\begin{abstract}
Environmental protection has globally driven the encouragement of design and development of low carbon supply chain management systems at global level. It is known that "Low carbon" approaches and principles play an effective role for industries to minimize the carbon emission from environment. In the real business environment, it becomes very difficult to select more relevant factors among various qualitative and quantitative variables involved in low carbon business operations. A novel hybrid MCDM model, which involved Decision making trial \& evaluation laboratory (DEMATEL), Analytical network process (ANP) and techniques for order performance by similarly to ideal solution (TOPSIS) followed by fuzzy methodologies has been developed for evaluation \& selection low carbon suppliers. In this paper, a novel hybrid framework has been proposed, which can provide sound support for implementations of LCSCM practices by effective evaluation of concerned criterions. However, some previous fuzzy methods are not capable to consider decision making randomness due to lack of concerned information.

The result shows that the novel hybrid MCDM approach to evaluate low carbon supplier to the improvement of LCSCM alternatives is the one which have greater final performance index having value of 0.2350 with corresponding index of supplier (T3), which is the best criteria in this method. Therefore, present work proposed a hybrid multi-criteria decision-making method using fuzzy DEMATEL-ANP-TOPSIS, which measured the cause and effect relationship shows the best result.

Keywords: Low carbon supply chain management (LCSCM), (MCDM) Multiple Criteria Decision Making; Fuzzy Analytic Network Process (FANP); Fuzzy Technique for Order Preference by Similarity to Ideal Solution (FTOPSIS), Fuzzy decision-making trial and evaluation laboratory' (fuzzy DEMATEL), Supplier selection, Decision making randomness.
\end{abstract}

\section{Introduction}

Past few years, design and development of indian industry improved in terms of manufacturing standard, which is the main reason for environment decay. In all developping countries like india the main focus of industries is to earn profit at low cost so the adoption of LCSCM system is necessary to protect environment. Low carbon supply chain management (LCSCM) system at global level has increased their importance because of increasing issues of environment. Presently the whole world together think about such environment protection for example "Kyoto Protocol" of kyoto city of japan held in 11 december 1997 which was the agreement between developing countries. According to this protocol all developing countries follows some environment healthy policies against these rapid industrialization. It is well known that the main purpose of all industries is to enhance their manufacturing performance and earn more profit but their statistics should be friendly for environment. LCSCM system give some suggestive policies to make a healthy corelation betwwen environment protection management and industrialization. By adopting all the issues, MCDM (Multi Criteria Decision Making) methods plays to be a strong role to make a great decision with better flexibility. To select the best supplier, these MCDM tools are proved to be a important technique. In present work, ANP \& TOPSIS tools are used to declaire these criterias performence as economic and environmental point of view.

DEMATEL method is used to establish the interrelation between available set of variables. The calculation part is done by applying microsoft excel \& MATLAB interface. The remaining part of present research is organized with the following steps: Step 2 shows the literature review of LCSCM applied supplier selection papers, Step 3 shows the flowchart of the study, Step 4 shows a case study problem in which the performance index is to be measured, step 5 shows some 
managerial implication and last step 6 shows conclusion \& results.

\section{Literature Review}

There are many issues in manufacturing industries, which imparts vital effect on environment includes: local environment, global environment, basic health issues etc. Past many years, there environmental problems has been considered. For the reduction of these issues, the low carbon supply chain management techniques are very useful. The interest of the industry regarding these techniques makes importance of suppliers selection in terms of environmental performance (Huzaifi., 2020; T. Fujisaki., 2016; H. Han., 2019) ${ }^{20-22)}$. All these techniques are important in terms of overall cost management (proper use of material, quality management, apply new advanced techniques in industry, proper human resource management etc). Production in the industry impart adverse effect on natural environment include use of raw materials, global atmosphere, health issue and some safety issues. These kinds of environment related issues increase the application of supply chain operation system within the industries. These increasingly application of supply chain system can raise the environmental importance \& performance of suppliers (A. Pal, K. Uddin., 2008; Yusei Masaki., 2016; Masahito Tanaka., 2017 ${ }^{23-25)}$. There are many benefits of this supply chain system for firm includes: overall reduction of cost (proper utilization of raw material, fines reduction, insurance price or risk reduction); increasing improvement of quality; application of rules and regulations; proper use of human resource management system (Aiello, G., 2009; X. Liu, Z. Tao, H. Chen, and L. Zhou., 2017; Amiri, M., Zandieh, M., Soltani, R., \& Vahdani, B.., 2009) ${ }^{17-19)}$. Low carbon supply chain management systems are become popular among practitioners and researchers. LCSC is a very good idea which include group of concepts which is useful for industry suppliers to improve the performance of their production process and quality products for both customers and suppliers. It has been seen in the past decade that LCSC management system provides the opportunities for industries to achieve sustainability and environmental goals. The commonly used LCSCM practices are supplier's environmental performance, suppliers to ensure the product quality against environment and for the examination of overall cost of waste material (Chen, S. J., \& Hwang, C. L., 1992; Chen-Yi, H., Ke-Ting, C., \& Gwo-Hshiung, T., 2007)26), 27). (Kumar, M., Vrat, P., \& Shankar, R., 2006) ${ }^{28)}$, explained the new principle of environmental Low Carbon supplier examination with the use of MCDM analysis method. (Lin, R.-H., 2009; Liou, J. J. H., Yen, L., \& Tzeng, G.-H., 2008; Liu, K. F. R., \& Lai, J.-H., 2009 $)^{29,-31)}$ proposed a linear possibilistic two-phase programming methodology for complex objective supplier examination and Green Disclosure Practices in
India. (Bhasin, Niti \& Kar., 2010) ${ }^{32}$, explained the performance of environmental suppliers by using Fuzzy MCDM methodology: fuzzy Preference organization ranking method for evaluations enrichment (PROMETHEE) hypothesis. In 2010,(Luo, Z.-M, Zhou, J.-Z., Zheng, L.-P., Mo, L., \& He, Y.-Y.) ${ }^{33)}$ Proposes examination of major waste industrial transportation with the use of multi step fuzzy TOPSIS and fuzzy AHP methodology. (Mohanty, R. P., Agarwal, (2005);

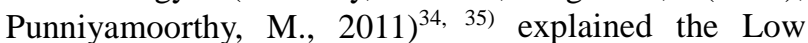
Carbon supplier hypothesis for firm. (Ramik, J., 2007) ${ }^{36)}$, proposes a novel MCDM technique based on fuzzy ANP, Fuzzy DEMATEL and fuzzy VIKOR for examination of watershed with the use of various strategies. (Roghanian, E., Rahimi, J., \& Ansari, A., 2010) $)^{37)}$, explains the evaluation of construction model projects and the interrelation between risk factors involved with the use of fuzzy DEMATEL \& fuzzy ANP techniques.

Table 1. Application areas of FANP-FDEMATEL-FTOPSIS

\begin{tabular}{|c|c|c|}
\hline $\begin{array}{l}\text { Sr. } \\
\text { No }\end{array}$ & $\begin{array}{l}\text { Author } \\
\text { Name }\end{array}$ & Applications \\
\hline 1 & $\begin{array}{l}\text { Büyüközkan } \\
\text { et al., } \\
(2012)^{12)}\end{array}$ & $\begin{array}{l}\text { Offer a more precise and accurate } \\
\text { analysis integrating } \\
\text { interdependent relationships within } \\
\text { and among a set of criteria. }\end{array}$ \\
\hline 2 & $\begin{array}{l}\text { Kuo et al., } \\
(2015)^{11)}\end{array}$ & $\begin{array}{l}\text { For evaluating carbon performance } \\
\text { of suppliers }\end{array}$ \\
\hline 3 & $\begin{array}{l}\text { Fahimeh et } \\
\text { al., }(2015)^{16)}\end{array}$ & $\begin{array}{l}\text { to evaluate and select advanced } \\
\text { manufacturing technologies }\end{array}$ \\
\hline 4 & $\begin{array}{l}\text { Uygun et al., } \\
(2016)^{10)}\end{array}$ & $\begin{array}{l}\text { The proposed method can be widely } \\
\text { used as a structural model for Low } \\
\text { Carbon supplier selection. }\end{array}$ \\
\hline 5 & $\begin{array}{l}\text { Tang et al., } \\
(2011)^{9)}\end{array}$ & $\begin{array}{l}\text { Application of the fuzzy analytic } \\
\text { hierarchy process to the lead-free } \\
\text { equipment selection decision }\end{array}$ \\
\hline 6 & $\begin{array}{l}\text { Kabir et al., } \\
(2011)^{8)}\end{array}$ & $\begin{array}{l}\text { Modified fuzzy analytical hierarchy } \\
\text { process } \\
\text { for multiple criteria inventory } \\
\text { classification }\end{array}$ \\
\hline 7 & $\begin{array}{l}\text { Ashrafzadeh } \\
.,(2012)^{7)}\end{array}$ & $\begin{array}{l}\text { The Application of Fuzzy Analytic } \\
\text { Hierarchy Process Approach for the } \\
\text { Selection of Warehouse Location: A } \\
\text { Case Study }\end{array}$ \\
\hline 8 & $\begin{array}{l}\text { Adelina et } \\
\text { al., }(2017)^{6)}\end{array}$ & $\begin{array}{l}\text { Evaluation of low carbon Supply } \\
\text { Chain Management Strategies }\end{array}$ \\
\hline 9 & $\begin{array}{l}\text { Ahmed et } \\
\text { al., }(2018)^{13)}\end{array}$ & $\begin{array}{l}\text { Organizations and decision makers } \\
\text { need to change their traditional } \\
\text { thinking when it comes to how to } \\
\text { manage SC }\end{array}$ \\
\hline 10 & $\begin{array}{l}\text { Shaverdi et } \\
\text { al., }(2016)^{5)}\end{array}$ & $\begin{array}{l}\text { Economic cocoon } \\
\text { improvement in silkworm breeding. }\end{array}$ \\
\hline 11 & $\begin{array}{l}\text { Ali Asghar., } \\
\left.(2013)^{4}\right)\end{array}$ & $\begin{array}{l}\text { Green Supply Chain Management } \\
\text { Evaluation in Publishing Industry } \\
\text { Based. }\end{array}$ \\
\hline 12 & $\begin{array}{l}\text { Lupo et al., } \\
(2013)^{3)}\end{array}$ & $\begin{array}{l}\text { Strategic Analysis of Transit Service } \\
\text { Quality. }\end{array}$ \\
\hline 13 & $\begin{array}{l}\text { Mohammad } \\
\text { et } \\
(2019)^{14)} \text { al., }\end{array}$ & $\begin{array}{l}\text { Developing a new model using } \\
\text { Fuzzy TOPSIS methods in supplier } \\
\text { selection problem in Supply Chain } \\
\text { Management-A case study of } \\
\text { SADRA Company in IRAN. }\end{array}$ \\
\hline 14 & $\begin{array}{l}\text { Tahrir et al., } \\
(2014)^{2)}\end{array}$ & $\begin{array}{l}\text { Supplier Assessment and Selection } \\
\text { Using Fuzzy Analytic Hierarchy } \\
\text { Process in a Steel Manufacturing } \\
\text { Company }\end{array}$ \\
\hline 15 & $\begin{array}{l}\text { Odeyale et } \\
\text { al., }(2014)^{1)}\end{array}$ & $\begin{array}{l}\begin{array}{l}\text { Evaluation and selection of an } \\
\text { effective green supply chain } \\
\text { management strategy: A case study. }\end{array}\end{array}$ \\
\hline 16 & $\begin{array}{l}\text { Pang et al., } \\
(2017)^{15)}\end{array}$ & $\begin{array}{l}\text { The proposed method can be widely } \\
\text { used as a structural model for Low } \\
\text { Carbon supplier selection. }\end{array}$ \\
\hline
\end{tabular}




\section{Proposed low carbon supplier examination framework}

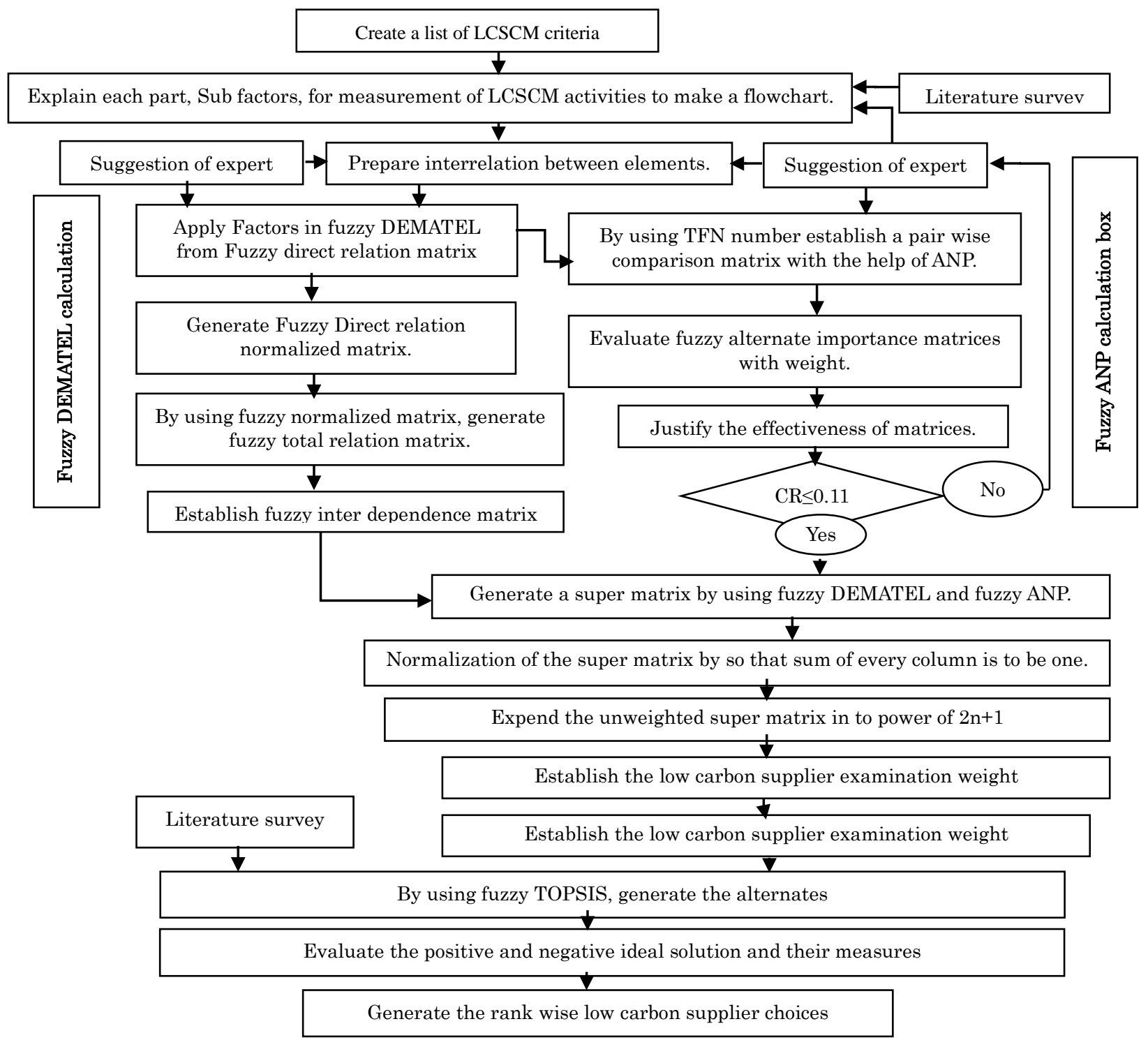

Fig.1: Methodology of proposed low carbon supply chain management model

Present work developed a novel hybrid approach followed by (FDEMATEL) fuzzy Decision-making trial \& evaluation laboratory, (FANP) fuzzy Analytical network process and (FTOPSIS) fuzzy techniques for order performance by similarly to ideal solution tools to get LCSCM strategic results. The basic model of LCSCM supplier examination framework is shown in figure1. First of all it is necessary to define the applied techniques, and next is to select the low carbon supplier examination criteria. The each model is divided into many sub sections ${ }^{38)}$.

\subsection{Proposed Approaches For The Low Carbon Supplier Examination Framework.}

3.1.1. FDEMATEL (Fuzzy Decision-Making Trial \& Evaluation Laboratory).
DEMATEL technique is used to solve complex problems associated with multiple structural factors. It was developed by Geneva institute of Battelle. By using this method, we can easily build and analyze structural model and produce a causal relationship between the different variables. DEMATEL is also useful to generate cause and relationship function. We can measure the exact real criteria of multiple variables by total relation matrix. Fuzzy associated with DEMATEL is used to solve complex problem by dividing the above problem into sub matrix which is shown in fig. 2 .

Choose the Examination Expert member committee

Identification of the barriers by literature survey and expert members suggestion.

Convert the responses into Fuzzy TFN 


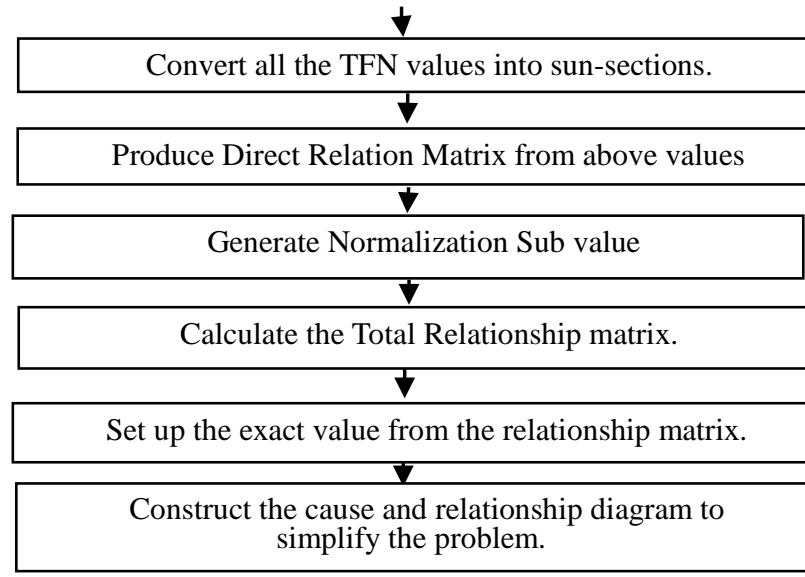

Fig.2: Steps of FDEMATEL technique.

\subsubsection{FANP (Fuzzy Analytical network process).}

ANP is originated by saaty $(1995)^{38)}$. In ANP technique, firstly we collect the project proposal from various resources (company employees, industry administrative staff). Generate a pool of the entire project or all possible solutions. From above all set, eliminate the less useful projects, and rest of the projects have been assigned to different department. Each of the department examined the all sets of variables and generates a report. Then collect all set of criteria from each department and generate an ANP network. Then calculate weighted decision matrix by all set of criteria. Next step is to generate unweighted super matrix. By calculating the super matrix, choose the best project from all. Step involved in FANP technique is shown in fig.3.

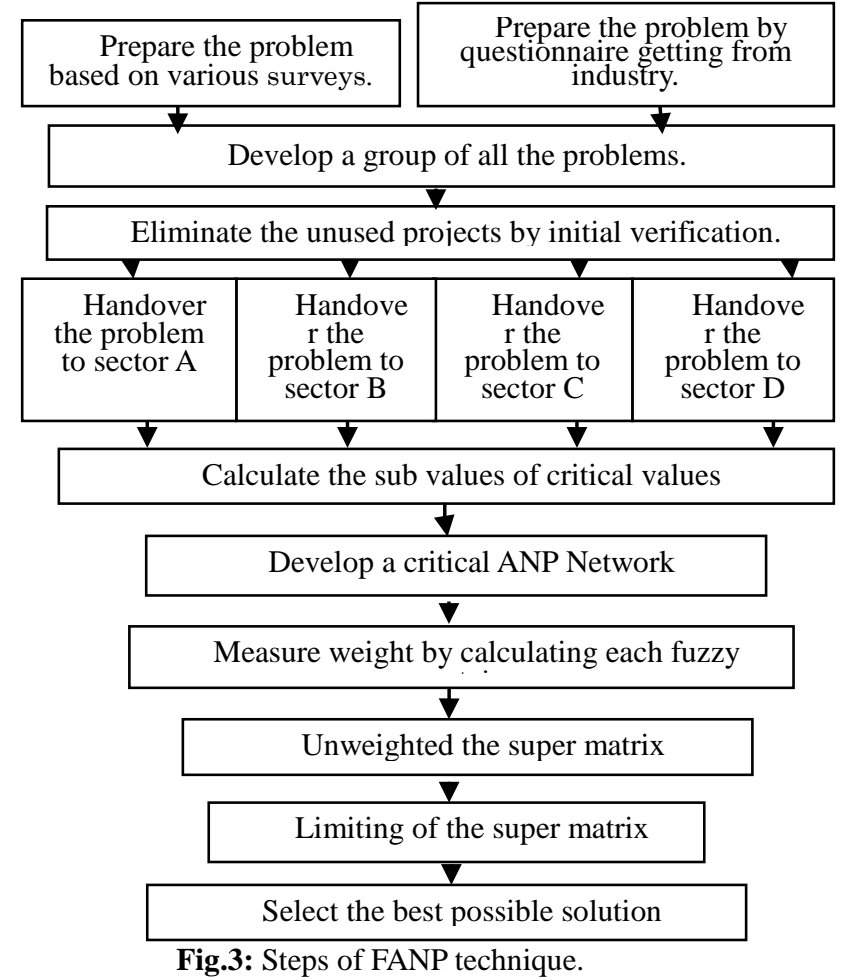

Fig.3: Steps of FANP technique.

\subsubsection{FTOPSIS (fuzzy techniques for order performance by similarly to ideal solution)}

The technique for order preference by similarity to an ideal solution (TOPSIS) was developed by Yoon \& Hwang (1982) which was experimented by HWANG \& Chen $(1993)^{26)}$. In this method we have to find out the value of ideal solution which has shortest distance from positive ideal solution and farthest distance from negative ideal solution. This technique contains following parts:

Part 1: Develop the fuzzy decision matrix.

Part 2: Develop normalized fuzzy decision matrix with the help of linguistic term and fuzzy set numbers.

Part 3: Calculate the weighted normalized fuzzy decision matrix \& compute the weighted value of each matrix.

Part 4: Develop the rank of the variables \& closeness coefficient of variables.

A system hierarchy A system network

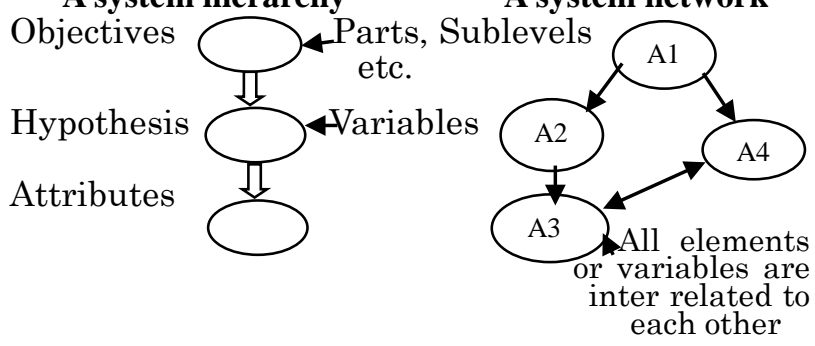

Fig.4: Difference between a system hierarchy and system network

\section{Low carbon logistics proportions:}

There are many complex internal and external elements \& variables, which is to be management with the proper use of LCSCM system. These variables are described by low carbon logistics proportions for the particular industry. These variables have their low to high priority such as manufacturing, distribution system, low carbon logistics system, packaging etc. the main factor, which is to be properly managed is the direct impact of these variables in the environment. First of all the selection of material used in the production industry is done on the basis of their ecofriendly nature. The pollution rate of all these materials should be minimum. The first part of the LCSCM system is the selection of vendor and procurement. The design of the production system is influenced by low carbon supply chain. All the internal factor and processes like TQM (Total quality management), Flexible manufacturing, raw material proper utilization, re cycling system, remanufacturing system etc are very useful for LCSCM.

Low carbon industrial activities proportions:

There are many low carbon industrial activities includes reusing, remanufacturing, recycling, disposal waste and reduce wastage of materials etc. the reusing part includes the resupply of the scrap or waste materials during production. During the production or 
manufacturing process in industry, some waste materials generate, which should be directly use again to manufacture the similar product that will increase the productivity and profit ratio of industry. Remanufacturing involves the again manufacturing of those products which are as good as parent products by setting up their quality standard and can be used for a long time. Recycling is the process by which used product can be recycled to make the similar product by improving their quality standard. All these important factors can increase the overall production of any industry. LCSCM process is directly associated with these factors.

\section{Industrial attainments proportions:}

The performance and attainment of a manufacturing industry is depending upon following factors:

\section{$>$ Average cost of product \\ $>$ Quality benchmark \\ $>\quad$ On time delivery and permeability etc.}

The performance of any industry is totally based on all these factors. If any industry follows all these rules, then environmental protection can be controlled. A good business perspective based industry should utilize all these factors effectively also it should support low carbon supply chain management processes. It has been seen that many researchers followed these attainments proportions in their literature. These performance indices are not static in nature but they change over time. The product life cycle is also influenced by them. In case of industrial attainment proportions, the least effective factor is cost, and most effective factors are time and flexibility.

Low carbon supplier examination assessment criteria:

For the examination of low carbon suppliers industry, many assessment criteria are as follows:

$>$ Financial based assessment

$>$ Man power based assessment

$>$ Advanced technology based assessment

$>$ Low carbon atmosphere based assessment

The advancement of all the factors shows the capability of industry in LCSCM system. Some of the critical factors like business atmosphere, close bonding and attitude towards quality show the appropriate use of LCSCM.

\section{Case Study}

\section{1 justification of examination framework in common manufacturing industry}

In a manufacturing industry many sub departments are involved in which each department has their own working cycle and production part. The assessment of the industry with effective LCSCM system is very important. The main factors of any general industry are industrial attainment, objective, low carbon logistics, low carbon supplier examination criteria and low carbon industrial activities etc.

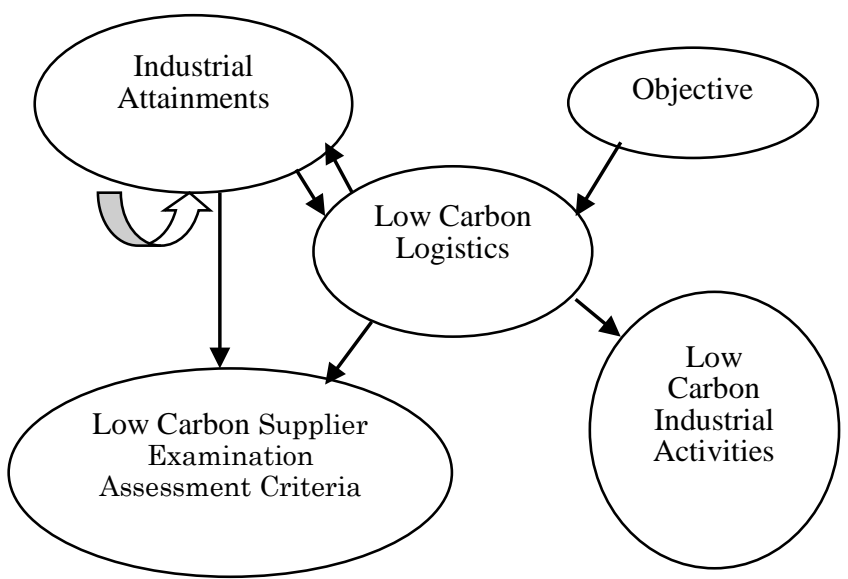

Fig.5: Examination framework network model

\subsection{Step wise demonstration of applied inter related framework}

Step 1: presentation of the hypothesis involved. Set up the objective of study and formed the expert committee with n number of members. Find out the attributes and format the criteria for examination of model. The evaluation criteria have already been discussed in the previous section in part 3.2. The examination model is shown in the fig- 4 .

Step 2: Establish the fuzzy linguistic term for the examination and build the relationship between the available variable with the help of expert committee opinion through group wise division analysis method. Table 1 shows the linguistic scale comparison between the effectiveness of all the variables.

There are eleven linguistic terms with their different degree of influence. The corresponding fuzzy membership functions for each linguistic term are shown in fig. 5. The casual relation between the variables is done by fuzzy DEMATEL.

Step 2.1: Prepare the direct relation fuzzy matrix. Pair wise matrix with their comparison has been made with the suggestion of expert in terms of direction and influence with criteria of $n \times n$ matrix $\dot{B}$, there $b_{i j}=\left(p_{i j}\right.$, $\mathrm{q}_{\mathrm{ij}}, \mathrm{r}_{\mathrm{ij}}$ ) which is denoted by the degree of randomness by which criteria i related to criteria $\mathrm{j}$. the direct relation fuzzy matrix is shown in the table 4 for industrial attainment proportions.

Step 2.2: Establish the normalization direct relation fuzzy matrix. By using DEMATEL method prepare the normalized fuzzy direct relation matrix with the help of relation matrix as discussed in the first step. The direct relation matrix $\dot{B}$ \& normalized direct relation matrix $\overline{\mathrm{Y}}$ is expressed by equation 1 .

The normalized direct relation matrix is expressed as:

$$
\begin{aligned}
& n \\
& \mathrm{~b}_{\mathrm{ij}}=\left(\mathrm{p}_{\mathrm{ij}}, \mathrm{q}_{\mathrm{ij}}, \mathrm{r}_{\mathrm{ij}}\right) \quad \text { and } \mathrm{B}=1 / \max _{1 \leq \mathrm{I} \leq \mathrm{n}} \sum \mathrm{r}_{\mathrm{ij}} \text {, then } \\
& \overline{\mathrm{Y}}=\mathrm{S} \times \overline{\mathrm{B}} \text {. } \\
& j=1
\end{aligned}
$$


Step 2.3: Compute the fuzzy total relation matrix with the help of given formula,

Let $\quad \overline{\mathrm{Y}}_{\mathrm{ij}}=\left(\mathrm{p}_{\mathrm{ij}}, \mathrm{q}_{\mathrm{ij}}, \mathrm{r}_{\mathrm{ij}}\right)$,

Then express all the three sub matrices, where the sub matrices are:

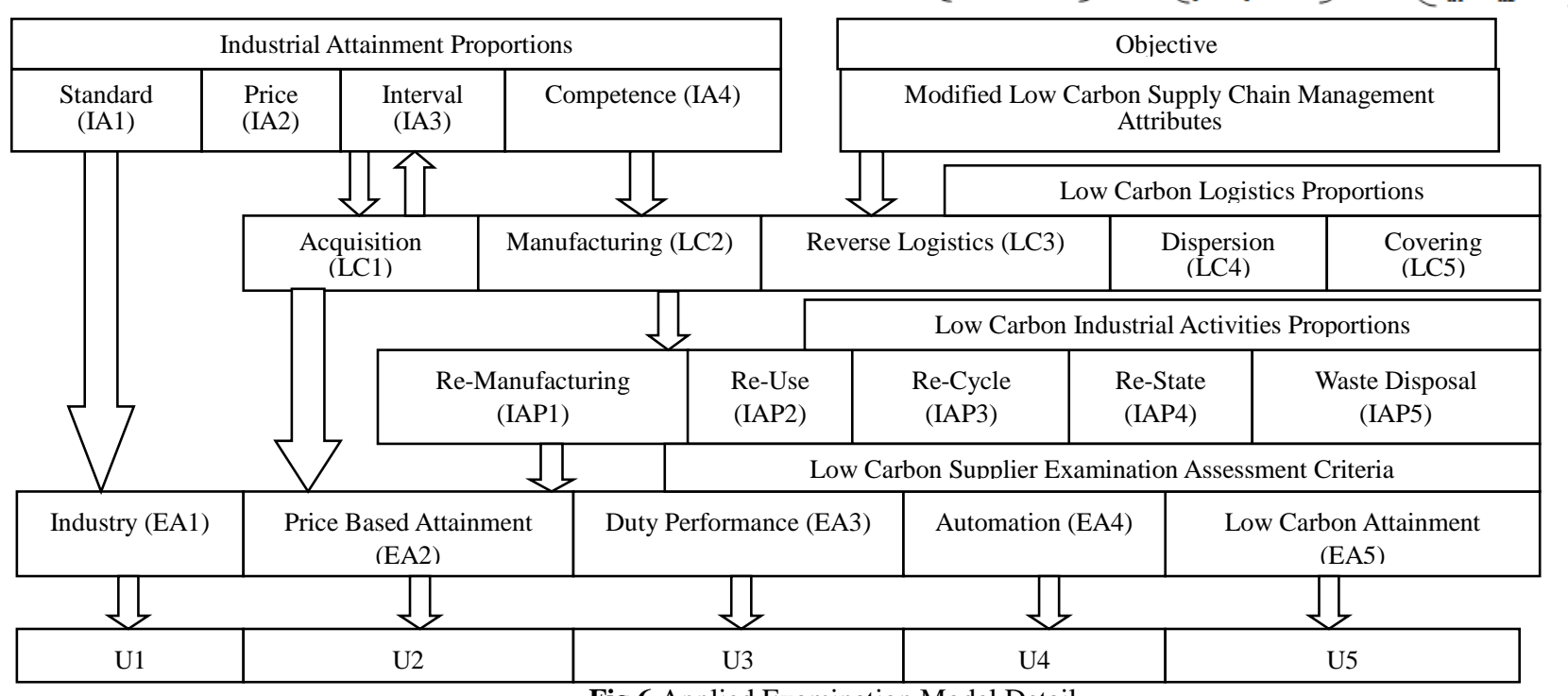

Fig.6 Applied Examination Model Detail

According to these sub matrices, we can define total relation matrix as:

$$
\overline{\mathbf{T}}=\overline{\mathrm{Y}}(\mathrm{I}-\overline{\mathrm{Y}})^{-1}
$$

Equation 4 shows the formula of total relation matrix. Step 2.4: Calculate inter dependent matrix. Defuzzify the total relation matrix $(\overline{\mathrm{T}})$ by the formula shown in equation (3) and draw the table such that the sum of each column in total relation matrix become equal to unity by using fuzzy normalization technique.

$$
\llbracket F\left(t \rrbracket_{i j}\right)=\left(\frac{1}{2}\right) \int_{0}^{1}\left(\operatorname { i n f } _ { \mathrm { x } \rightarrow \infty } \left(t \rrbracket_{i j}+\sup _{x \rightarrow \infty}\left(t \rrbracket_{i j}\right) d x\right.\right.
$$

The unweighted super matrix of ANP will be acquired

\begin{tabular}{|c|c|c|c|}
\hline Applied Term & Abbreviation & $\begin{array}{c}\text { Value of Fuzzy } \\
\text { Scale }\end{array}$ & $\begin{array}{c}\text { Fuzzy } \\
\text { Analytical } \\
\text { Network } \\
\text { Process }\end{array}$ \\
\hline Blank & $\mathrm{NO}$ & $(0,0,1)$ & $(\infty, \infty, 1)$ \\
\hline Too Low & VLO & $(0,0.11,0.21)$ & $\begin{array}{c}(0,1 / 0.11, \\
1 / 0.21)\end{array}$ \\
\hline Low & LO & $(0.11,0.21,0.31)$ & $\begin{array}{c}(1 / 0.11,1 / 0.21, \\
1 / 0.31)\end{array}$ \\
\hline Little Low & FLO & $(0.21,0.31,0.41)$ & $\begin{array}{c}(1 / 0.21,1 / 0.31, \\
1 / 0.41)\end{array}$ \\
\hline $\begin{array}{l}\text { Greater or } \\
\text { Smaller Low }\end{array}$ & MLO & $(0.31,0.41,0.51)$ & $\begin{array}{c}(1 / 0.31,1 / 0.41, \\
1 / 0.51)\end{array}$ \\
\hline Middle Value & MD & $(0.41,0.51,0.61)$ & $\begin{array}{c}(1 / 0.41,1 / 0.51, \\
1 / 0.61)\end{array}$ \\
\hline $\begin{array}{l}\text { Greater or } \\
\text { Smaller Good }\end{array}$ & MDG & $(0.51,0.61,0.71)$ & $\begin{array}{c}(1 / 0.51,1 / 0.61, \\
1 / 0.71)\end{array}$ \\
\hline Little Good & FGD & $(0.61,0.71,0.81)$ & $\begin{array}{c}(1 / 0.61,1 / 0.71, \\
1 / 0.81)\end{array}$ \\
\hline Good & GD & $(0.71,0.81,0.91)$ & $\begin{array}{c}(1 / 0.71,1 / 0.81, \\
1 / 0.91)\end{array}$ \\
\hline & VGD & $(0.81,0.91$ & $\begin{array}{c}(1 / 0.81,1 / 0.91, \\
1)\end{array}$ \\
\hline Ex & EL & $(0.91,1$ & $(1 / 0.91,1,1)$ \\
\hline
\end{tabular}

Table 2. Linguistic scales for relative importance with the use of inter dependent matrix. The inter dependent matrix for industrial attainment proportion is shown in table 7 and it is denoted by matrix $\dot{B}$ of the super matrix.

Step 3: Fuzzy ANP technique is applied in this step. In case of ANP method, pair wise allocation \& comparison of all variables in each part are calculated with the help of their comparative importance.

Then the strength of each pair of elements are calculated through triangular fuzzy numbers and indicated the preference of the decision made with the similar hierarchy.

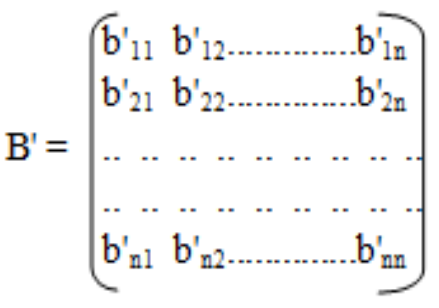

Where $b_{i j}^{\prime}=\left(p_{i j}^{\prime}, q_{i j}^{\prime}, r_{i j}^{\prime}\right)$ shows the comparative preferences of criteria (preference $i$ as compared to $j$ ), where $\mathrm{i}=\mathrm{J}=1,2,3, \ldots \ldots \ldots \ldots \ldots . \mathrm{n}$.

The matrix of linguistic scale \& fuzzy examination between low carbon logistics proportions and objective for examination is shown in fig. 6 which is matrix B of super matrix.

Step 3.1: Evaluate the comparative preferences weight. The preference vector of each pair wise comparative matrix needs to justify all super matrices with sub matrix. 
Compute the value of $\mathrm{w}_{\mathrm{k}}$ (triangular fuzzy priorities) where $\mathrm{k}=1,2,3, \ldots \ldots \ldots \ldots$..... from the justified matrix. To calculate the value of each weight, use logarithmic least square technique.

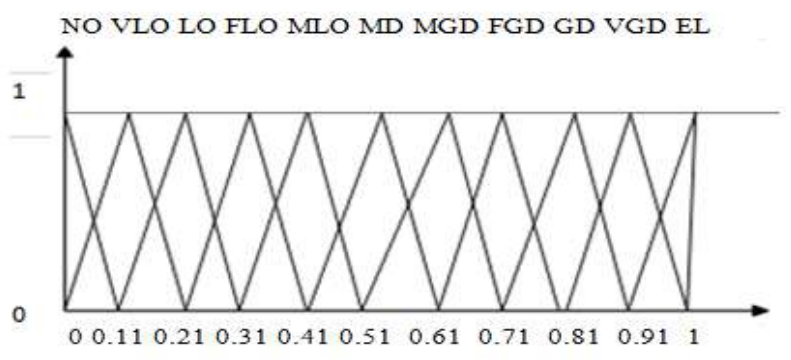

Fig.6: Fuzzy Triangular membership function for linguistic values.

Table 3: Abbreviation for super matrix with their matrix

\begin{tabular}{|c|c|c|c|c|c|}
\hline & $\begin{array}{c}\text { Object } \\
\text { ive }\end{array}$ & LCP & IA & $\begin{array}{c}\text { IA } \\
\mathbf{P}\end{array}$ & EA \\
\hline Objective & 0 & 0 & 0 & 0 & 0 \\
\hline $\begin{array}{c}\text { Low Carbon Logistics Proportions } \\
\text { (LCP) }\end{array}$ & $\mathrm{B}$ & $\mathrm{F}$ & $\mathrm{E}$ & 0 & 0 \\
\hline Industrial Attainment (IA) & 0 & $\mathrm{E}$ & $\mathrm{C}$ & 0 & 0 \\
\hline $\begin{array}{c}\text { Low Carbon Industrial Activities } \\
\text { Proportions (IAP) }\end{array}$ & 0 & $\mathrm{D}$ & 0 & 0 & 0 \\
\hline $\begin{array}{c}\text { Low Carbon Supplier Examination } \\
\text { Assessment Criteria (EA) }\end{array}$ & 0 & $\mathrm{G}$ & $\mathrm{H}$ & $\mathrm{J}$ & 0 \\
\hline
\end{tabular}

Where $\quad \mathrm{w}_{\mathrm{k}}=\left(\mathrm{w}_{\mathrm{tk}}^{\mathrm{p}}, \mathrm{w}_{\mathrm{tk}}{ }^{\mathrm{q}}, \mathrm{w}_{\mathrm{tk}}^{\mathrm{r}}\right)$, where $\mathrm{k}=$ $1,2,3, \ldots \ldots \ldots \ldots . n$

Step 3.2: Defuzzification is done for all weight which are measured from fuzzy matrices. The preference of defuzzification is same as discussed in previous part in $\mathrm{w}_{\mathrm{tk}} \mathrm{p}=\frac{(0.21 \times 0.11 \times 0.61 \times 1 / 1 \times 1)^{1 / 5}}{(1 \times 0.91 \times 1 / 0.41 \times 1 / 0.31 \times 1 / 0.31)^{1 / 5}+(1 \times 0.91 \times 1 / 0.41 \times}$

$$
(1 \times 0.91 \times 1 / 0.41 \times 1 / 0.31 \times 1 / 0.31)^{1 / 5}+(1 \times 0.91 \times 1 / 0.41 \times 1 / 0.21 \times 1 / 0.21)^{1 / 5}+
$$

$(0.41 \times 0.41 \times 1 \times 1 / 071 \times 1 / 0.71)^{1 / 5}+(0.31 \times 0.21 \times 0.71 \times 1 \times 1)^{1 / 5}+(0.31 \times 0.21 \times 0.71 \times 1 / 1 \times 1)^{1 / 5}$

$$
\begin{array}{rlr}
\mathrm{W}_{\mathrm{tk}}{ }^{\mathrm{q}}= & \frac{(0.31 \times 0.21 \times 0.71 \times 1 / 1 \times 1)^{1 / 5}}{(1 \times 0.91 \times 1 / 0.41 \times 1 / 0.31 \times 1 / 0.31)^{1 / 5}+(1 \times 0.91 \times 1 / 0.41 \times 1 / 0.21 \times 1 / 0.21)^{1 / 5}+} & 0.08962 \\
& (0.41 \times 0.41 \times 1 \times 1 / 071 \times 1 / 0.71)^{1 / 5}+(0.31 \times 0.21 \times 0.71 \times 1 \times 1)^{1 / 5}+(0.31 \times 0.21 \times 0.71 \times 1 / 1 \times 1)^{1 / 5} & \\
\mathrm{~W}_{\mathrm{tk}}{ }^{\mathrm{r}}=\frac{(0.41 \times 0.31 \times 0.81 \times 1 / 0.91 \times 1)^{1 / 5}}{(1 \times 0.91 \times 1 / 0.41 \times 1 / 0.31 \times 1 / 0.31)^{1 / 5}+(1 \times 0.91 \times 1 / 0.41 \times 1 / 0.21 \times 1 / 0.21)^{1 / 5}+} & 0.10722
\end{array}
$$

$(0.41 \times 0.41 \times 1 \times 1 / 071 \times 1 / 0.71)^{1 / 5}+(0.31 \times 0.21 \times 0.71 \times 1 \times 1)^{1 / 5}+(0.31 \times 0.21 \times 0.71 \times 1 / 1 \times 1)^{1 / 5}$

With the use of fuzzy vector \&using equation-6, defuzzified weight 0.08918 is measured.

Step 4: In the super matrix, ANP technique is used to measure the effect of inter dependent matrix which is exist between the complex structures of decision matrix hierarchy. The mentioned super matrix is dividend matrix, in which each pair of super matrix shows the relationship between the variables shown in the designed model. The systematic matrix is shown in Table 3, with the abbreviation of each relationship matrix. The initial super matrix was made with the prime concern of fuzzy

\begin{tabular}{|c|c|c|c|c|}
\hline & $\begin{array}{c}\text { Standard } \\
\text { (IA1) }\end{array}$ & Price (IA2) & $\begin{array}{c}\text { Interval } \\
\text { (IA3) }\end{array}$ & \begin{tabular}{|c|} 
Competen \\
ce (IA4)
\end{tabular} \\
\hline \multirow{2}{*}{$\begin{array}{c}\text { Standard } \\
\text { (IA1) }\end{array}$} & \multirow{2}{*}{0} & $(0.36,0.36,0$. & \multicolumn{2}{|c|}{$(0.18,0.20,0).(0,0.04,0.0$} \\
\hline & & 36) & 22) & 7) \\
\hline $\begin{array}{l}\text { Price } \\
\text { (IA2) }\end{array}$ & $\begin{array}{c}(0.23,0.24,0 . \\
25)\end{array}$ & 0 & $\begin{array}{c}(0.18,0.20,0 \\
22)\end{array}$ & $(0,0,0.04)$ \\
\hline $\begin{array}{c}\text { Interval } \\
\text { (IA3) }\end{array}$ & $\begin{array}{c}(0.18,0.20,0 . \\
22)\end{array}$ & $\begin{array}{c}(0.61,0.28,0 . \\
29)\end{array}$ & 0 & $\begin{array}{c}(0,0.04,0.0 \\
7)\end{array}$ \\
\hline $\begin{array}{c}\text { Competen } \\
\text { ce (IA4) }\end{array}$ & $\begin{array}{c}(0.14,0.16,0 . \\
18)\end{array}$ & $\begin{array}{c}(0.36,0.36,0 . \\
36)\end{array}$ & $\begin{array}{c}(0.23,0.24,0 \\
25)\end{array}$ & 0 \\
\hline
\end{tabular}
DEMATEL \& fuzzy ANP in their respective column. The first super matrix is shown in the table 9 .

Table 5. Fuzzy normal relation direct matrix of industrial attainment proportions.
Table 6. Fuzzy total relation direct matrix of industrial attainment proportions.

\begin{tabular}{|c|c|c|c|c|}
\hline & $\begin{array}{c}\text { Standard } \\
\text { (IA1) }\end{array}$ & $\begin{array}{c}\text { Price } \\
\text { (IA2) }\end{array}$ & $\begin{array}{c}\text { Interval } \\
\text { (IA3) }\end{array}$ & $\begin{array}{c}\text { Compet } \\
\text { ence }\end{array}$ \\
\hline
\end{tabular}




\begin{tabular}{|c|c|c|c|c|}
\hline & & & & (IA4) \\
\hline $\begin{array}{l}\text { Standar } \\
\text { d (IA1) }\end{array}$ & $\begin{array}{c}(0.17,0.22, \\
0.29) \\
\end{array}$ & $\begin{array}{c}(0.5,0.57,0 \\
.65) \\
\end{array}$ & $\begin{array}{c}(0.3,0.37,0 \\
.47) \\
\end{array}$ & $\begin{array}{c}(0,0.06,0 \\
.15) \\
\end{array}$ \\
\hline $\begin{array}{l}\text { Price } \\
\text { (IA2) } \\
\end{array}$ & $\begin{array}{c}(0.32,0.37 \\
0.44)\end{array}$ & $\begin{array}{c}(0.19,0.23, \\
0.32)\end{array}$ & $\begin{array}{c}(0.27,0.33, \\
0.42)\end{array}$ & $\begin{array}{c}(0,0.03,0 \\
.11) \\
\end{array}$ \\
\hline $\begin{array}{c}\text { Interval } \\
\text { (IA3) }\end{array}$ & $\begin{array}{c}(0.3,0.36,0 \\
.45)\end{array}$ & $\begin{array}{c}(0.41,0.48 \\
0.58)\end{array}$ & $\begin{array}{c}(0.13,0.18 \\
0.26)\end{array}$ & $\begin{array}{c}(0,0.06,0 \\
.14)\end{array}$ \\
\hline $\begin{array}{l}\text { Compet } \\
\text { ence } \\
\text { (IA4) }\end{array}$ & $\begin{array}{c}(0.35,0.41 \\
0.5)\end{array}$ & $\begin{array}{c}(0.59,0.65 \\
0.74)\end{array}$ & $\begin{array}{c}(0.4,0.46,0 \\
.55)\end{array}$ & $\begin{array}{c}(0,0.04,0 \\
.1)\end{array}$ \\
\hline
\end{tabular}

Step 4.1: The first part is to do the normalization of each column, which is obtained by dividing each weight in column by sum of all weight in the column. Then in the next part, set up the ranking of each variable according to their priorities. Similarly repeat this procedure for all weight \& find out overall priorities. Then obtain the cumulative influence of each and every variable in the super matrix which is shown in table. 10 .

Step 5: Apply fuzzy TOPSIS technique to evaluate the alternatives of each variables, which can be as follows:

Step 5.1: Prepare fuzzy decision matrix for examination of the low carbon supplier variables, which contains a variables and b criteria. The fuzzy MCDM approach is shown in the below procedure.

Table 7. Fuzzy inter dependent matrix of industrial attainment proportions.

\begin{tabular}{|c|c|c|c|c|}
\hline & $\begin{array}{c}\text { Standar } \\
\text { d (IA1) }\end{array}$ & $\begin{array}{c}\text { Price } \\
\text { (IA2) }\end{array}$ & $\begin{array}{c}\text { Interval } \\
\text { (IA3) }\end{array}$ & $\begin{array}{c}\text { Competenc } \\
\text { e (IA4) }\end{array}$ \\
\hline $\begin{array}{c}\text { Standard } \\
\text { (IA1) }\end{array}$ & 0.205 & 0.285 & 0.303 & 0.294 \\
\hline Price (IA2) & 0.245 & 0.165 & 0.231 & 0.205 \\
\hline $\begin{array}{c}\text { Interval } \\
\text { (IA3) }\end{array}$ & 0.265 & 0.24 & 0.154 & 0.285 \\
\hline $\begin{array}{c}\text { Competenc } \\
\text { e (IA4) }\end{array}$ & 0.285 & 0.31 & 0.312 & 0.216 \\
\hline
\end{tabular}

Table 8. Linguistic variable and fuzzy examination matrices of low carbon logistics associated with objective.

\begin{tabular}{|c|c|c|c|c|c|c|c|c|c|}
\hline \multicolumn{9}{|c|}{ Linguistic Notation } & \multicolumn{5}{c|}{ Fuzzy associated terms } \\
\hline LC1 & LC2 & LC3 & LC4 & LC5 & LC1 & LC2 & LC3 & LC4 & LC5 \\
\hline 1 & VGD & & & & 1 & $(0.81,0.91,1)$ & $(1 / 0.51,1 / 0.41,1 / 0.31$ & $(1 / 0.41,1 / 0.31,1 / 0.21$ & $(1 / 0.41,1 / 0.31,1 / 0.21$ \\
\hline & 1 & & & & $(1 / 1,1 / 0.91,1 / 0.81)$ & 1 & $(1 / 0.51,1 / 0.41,1 / 0.31)$ & $(1 / 0.31,1 / 0.21,1 / 0.11)$ & $(1 / 0.31,1 / 0.21,1 / 0.11)$ \\
\hline MLO & MLO & 1 & & & $(0.31,0.41,0.51)$ & $(0.31,0.41,0.51)$ & 1 & $(1 / 0.81,1 / 0.71,1 / 0.61)$ & $(1 / 0.81,1 / 0.71,1 / 0.61)$ \\
\hline FLO & LO & FGD & 1 & EL & $(0.21,0.31,0.41)$ & $(0.11,0.21,0.31)$ & $(0.61,0.71,0.81)$ & 1 & $(0.91,1,1)$ \\
\hline FLO & LO & FGD & & 1 & $(0.21,0.31,0.41)$ & $(0.11,0.21,0.31)$ & $(0.61,0.71,0.81)$ & $(1 / 1,1 / 1,1 / 0.91)$ & 1 \\
\hline
\end{tabular}

Table 9. Starting Super matrix of low carbon supplier selection for the improvement of LCSC.

\begin{tabular}{|c|c|c|c|c|c|c|c|c|c|c|c|c|c|c|c|c|c|c|c|c|}
\hline & $\begin{array}{c}\text { Objecti } \\
\text { ve }\end{array}$ & LC1 & LC2 & LC3 & LC4 & LC5 & IA1 & IA2 & IA3 & IA4 & IAP1 & IAP2 & IAP3 & IAP4 & IAP5 & D1 & D2 & D3 & D4 & D5 \\
\hline Objective & 0 & 0 & 0 & 0 & 0 & 0 & 0 & 0 & 0 & 0 & 0 & 0 & 0 & 0 & 0 & 0 & 0 & 0 & 0 & 0 \\
\hline LC1 & 0.44 & 0.1 & 0.3 & 0.3 & 0.2 & 0.3 & 0.2 & 0.5 & 0.1 & 0.1 & 0 & 0 & 0 & 0 & 0 & 0 & 0 & 0 & 0 & 0 \\
\hline LC2 & 0.53 & 0.4 & 0.2 & 0.2 & 0.2 & 0.3 & 0.3 & 0.3 & 0.3 & 0.2 & 0 & 0 & 0 & 0 & 0 & 0 & 0 & 0 & 0 & 0 \\
\hline LC3 & 0.14 & 0.1 & 0.1 & 0.1 & 0.2 & 0.1 & 0.2 & 0.3 & 0.3 & 0.4 & 0 & 0 & 0 & 0 & 0 & 0 & 0 & 0 & 0 & 0 \\
\hline LC4 & 0.09 & 0.2 & 0.3 & 0.2 & 0.2 & 0.1 & 0.2 & 0.1 & 0.2 & 0.2 & 0 & 0 & 0 & 0 & 0 & 0 & 0 & 0 & 0 & 0 \\
\hline LC5 & 0.1 & 0.2 & 0.1 & 0.2 & 0.2 & 0.2 & 0.1 & 0.1 & 0.1 & 0.1 & 0 & 0 & 0 & 0 & 0 & 0 & 0 & 0 & 0 & 0 \\
\hline IA1 & 0 & 0.6 & 0.1 & 0.2 & 0.2 & 0.5 & 0.205 & 0.285 & 0.303 & 0.294 & 0 & 0 & 0 & 0 & 0 & 0 & 0 & 0 & 0 & 0 \\
\hline IA2 & 0 & 0.2 & 0.1 & 0.1 & 0.5 & 0.2 & 0.245 & 0.165 & 0.231 & 0.205 & 0 & 0 & 0 & 0 & 0 & 0 & 0 & 0 & 0 & 0 \\
\hline IA3 & 0 & 0.1 & 0.3 & 0.6 & 0.3 & 0.2 & 0.265 & 0.24 & 0.154 & 0.285 & 0 & 0 & 0 & 0 & 0 & 0 & 0 & 0 & 0 & 0 \\
\hline IA4 & 0 & \begin{tabular}{|l|}
0.1 \\
\end{tabular} & 0.5 & 0.2 & 0.1 & 0.1 & 0.285 & 0.31 & 0.312 & 0.216 & 0 & 0 & 0 & 0 & 0 & 0 & 0 & 0 & 0 & 0 \\
\hline IAP1 & 0 & \begin{tabular}{|l|}
0.4 \\
\end{tabular} & 0.4 & 0.5 & 0.5 & 0.4 & 0 & 0 & 0 & 0 & 0 & 0 & 0 & 0 & 0 & 0 & 0 & 0 & 0 & 0 \\
\hline IAP2 & 0 & 0.1 & 0.1 & 0.1 & 0.1 & 0.2 & 0 & 0 & 0 & 0 & 0 & 0 & 0 & 0 & 0 & 0 & 0 & 0 & 0 & 0 \\
\hline IAP3 & 0 & \begin{tabular}{|l|}
0.2 \\
\end{tabular} & 0.2 & 0.2 & 0.2 & 0.2 & 0 & 0 & 0 & 0 & 0 & 0 & 0 & 0 & 0 & 0 & 0 & 0 & 0 & 0 \\
\hline IAP4 & 0 & 0.3 & 0.3 & 0.3 & 0.2 & 0.2 & 0 & 0 & 0 & 0 & 0 & 0 & 0 & 0 & 0 & 0 & 0 & 0 & 0 & 0 \\
\hline IAP5 & 0 & 0.1 & 0.1 & 0.1 & 0.1 & 0.1 & 0 & 0 & 0 & 0 & 0 & 0 & 0 & 0 & 0 & 0 & 0 & 0 & 0 & 0 \\
\hline D1 & 0 & 0.2 & 0.2 & 0.2 & 0.2 & 0.2 & 0.2 & 0.2 & 0.2 & 0.2 & 0.14 & 0.14 & 0.14 & 0.19 & 0.21 & 0 & 0 & 0 & 0 & 0 \\
\hline D2 & 0 & \begin{tabular}{|l|}
0.2 \\
\end{tabular} & 0.2 & 0.3 & 0.1 & 0.2 & 0.3 & 0.3 & 0.3 & 0.2 & 0.15 & 0.14 & 0.14 & 0.19 & \begin{tabular}{|l|}
0.21 \\
\end{tabular} & 0 & 1 & 0 & 0 & 0 \\
\hline D3 & 0 & 0.3 & 0.3 & 0.2 & 0.3 & 0.2 & 0.2 & 0.1 & 0.2 & 0.3 & 0.18 & 0.14 & 0.14 & 0.19 & 0.21 & 0 & 0 & 1 & 0 & 0 \\
\hline D4 & 0 & 0.2 & 0.2 & 0.2 & 0.2 & 0.2 & 0.1 & 0.3 & 0.1 & 0.2 & 0.25 & 0.24 & 0.33 & 0.22 & 0.14 & 0 & 0 & 0 & 1 & 0 \\
\hline D5 & 0 & 0.1 & 0.1 & 0.1 & 0.2 & 0.2 & 0.2 & 0.1 & 0.2 & 0.1 & 0.28 & 0.34 & 0.25 & 0.21 & \begin{tabular}{|l}
0.23 \\
\end{tabular} & 0 & 0 & 0 & 0 & 1 \\
\hline
\end{tabular}

Table 10. Weighted Super matrix of low carbon supplier selection for the improvement of LCSC.

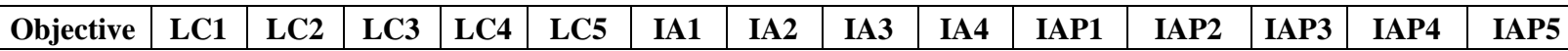




\begin{tabular}{|l|l|l|l|l|l|l|l|l|l|l|l|l|l|l|l|} 
D1 & 0.19 & 0.16 & 0.15 & 0.16 & 0.17 & 0.14 & 0.17 & 0.14 & 0.21 & 0.25 & 0.12 & 0.12 & 0.12 & 0.18 & 0.21 \\
\hline D2 & 0.23 & 0.21 & 0.16 & 0.18 & 0.18 & 0.19 & 0.21 & 0.21 & 0.15 & 0.27 & 0.14 & 0.14 & 0.14 & 0.15 & 0.18 \\
\hline D3 & 0.21 & 0.19 & 0.18 & 0.21 & 0.17 & 0.11 & 0.22 & 0.22 & 0.21 & 0.11 & 0.18 & 0.14 & 0.15 & 0.15 & 0.14 \\
\hline D4 & 0.18 & 0.22 & 0.22 & 0.17 & 0.21 & 0.27 & 0.21 & 0.22 & 0.22 & 0.18 & 0.22 & 0.28 & 0.25 & 0.21 & 0.21 \\
\hline D5 & 0.19 & 0.22 & 0.29 & 0.28 & 0.27 & 0.29 & 0.19 & 0.21 & 0.21 & 0.19 & 0.34 & 0.32 & 0.34 & 0.31 & 0.26 \\
\hline
\end{tabular}

Table 11. Linguistic and fuzzy decision matrix for low carbon suppliers.

\begin{tabular}{|c|c|c|c|c|c|c|c|c|c|c|}
\hline & D1 & D2 & D3 & D4 & D5 & D1 & D2 & D3 & D4 & D5 \\
\hline T1 & FGD & GD & FGD & MGD & MLO & $(0.61,0.71,0.81)$ & $(0.71,0.81,0.91)$ & $(0.61,0.71,0.81)$ & $(0.51,0.61,0.71)$ & $(0.31,0.41,0.51)$ \\
\hline T2 & VGD & GD & GD & VGD & VGD & $(0.81,0.91,1)$ & $(0.71,0.81,0.91)$ & $(0.71,0.81,0.91)$ & $(0.81,0.91,1)$ & $(0.81,0.91,1)$ \\
\hline T3 & VGD & EL & EL & GD & GD & $(0.81,0.91,1)$ & $(0.91,1,1)$ & $(0.91,1,1)$ & $(0.71,0.81,0.91)$ & $(0.71,0.81,0.91)$ \\
\hline T4 & MGD & VGD & GD & VGD & MGD & $(0.51,0.61,0.71)$ & $(0.81,0.91,1)$ & $(0.71,0.81,0.91)$ & $(0.81,0.91,1)$ & $(0.51,0.61,0.71)$ \\
\hline T5 & MGD & MGD & FGD & GD & GD & $(0.41,0.51,0.61)$ & $(0.51,0.61,0.71)$ & $(0.61,0.71,0.81)$ & $(0.71,0.81,0.91)$ & $(0.71,0.81,0.91)$ \\
\hline
\end{tabular}

Table 12. Weighted decision matrix for low carbon supplier examination.

\begin{tabular}{|c|c|c|c|c|c|}
\hline & D1 & D2 & D3 & D4 & D5 \\
\hline T1 & $(0.13,0.15,0.18)$ & $(0.16,0.19,0.23)$ & $(0.13,0.15,0.18)$ & $(0.16,0.19,0.23)$ & $(0.08,0.10,0.12)$ \\
\hline T2 & $(0.16,0.18,0.22)$ & $(0.16,0.19,0.23)$ & $(0.18,0.21,0.23)$ & $(0.23,0.25,0.28)$ & $(0.23,0.25,0.28)$ \\
\hline T3 & $(0.16,0.18,0.22)$ & $(0.23,0.25,0.28)$ & $(0.23,0.25,0.28)$ & $(0.18,0.21,0.23)$ & $(0.18,0.21,0.23)$ \\
\hline T4 & $(0.10,0.15,0.17$ & $(0.18,0.21,0.23)$ & $(0.18,0.21,0.23)$ & $(0.23,0.25,0.28)$ & $(0.13,0.15,0.18)$ \\
\hline T5 & $(0.08,0.10,0.12)$ & $(0.13,0.15,0.18)$ & $(0.13,0.15,0.18)$ & $(0.18,0.21,0.23)$ & $(0.18,0.21,0.23)$ \\
\hline
\end{tabular}

Table 13. Fuzzy standardized direct connection matrix of industrial attainment proportion.

\begin{tabular}{|c|c|c|c|c|c|c|c|c|c|c|c|c|}
\hline \multicolumn{9}{|c|}{ Positive } & \multicolumn{1}{|c|}{ Negative } \\
\hline & E1 & E2 & E3 & E4 & E5 & EтоT & E1 & E2 & E3 & E4 & E5 & ETOT \\
\hline T1 & 0.99 & 0.98 & 1.02 & 0.94 & 1.03 & 4.96 & 0.15 & 0.19 & 0.15 & 0.19 & 0.1 & 0.78 \\
\hline T2 & 0.98 & 0.98 & 0.96 & 0.87 & 0.91 & 4.7 & 0.18 & 0.19 & 0.21 & 0.25 & 0.25 & 1.08 \\
\hline T3 & 0.98 & 0.93 & 0.93 & 0.92 & 0.92 & 4.68 & 0.18 & 0.25 & 0.25 & 0.21 & 0.21 & 1.10 \\
\hline T4 & 1.02 & 0.94 & 0.95 & 0.88 & 0.99 & 4.78 & 0.15 & 0.21 & 0.21 & 0.25 & 0.15 & 0.97 \\
\hline T5 & 0.57 & 1.02 & 0.99 & 0.92 & 0.92 & 4.42 & 0.10 & 0.15 & 0.15 & 0.21 & 0.21 & 0.82 \\
\hline
\end{tabular}

Table 14. Final performance index for low carbon supplier alternatives.

\begin{tabular}{|c|c|}
\hline \multicolumn{2}{|c|}{ Performance index } \\
\hline T1 & 0.1573 \\
\hline T2 & 0.2298 \\
\hline T3 & 0.2350 \\
\hline T4 & 0.2029 \\
\hline T5 & 0.1855 \\
\hline
\end{tabular}

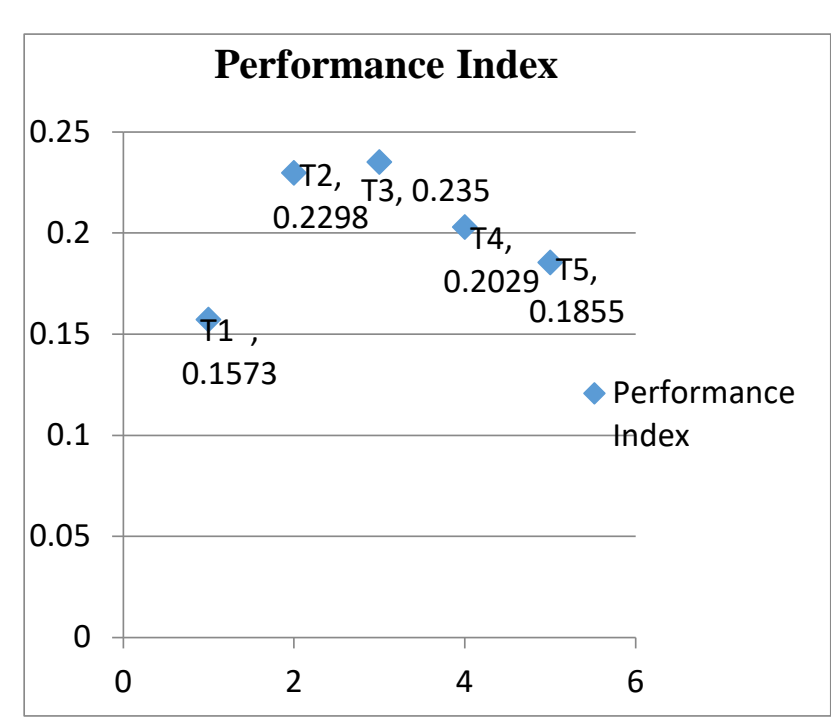

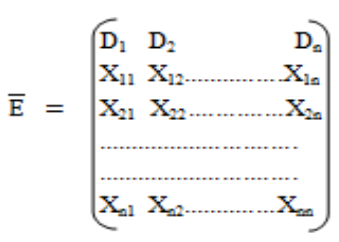

Where $\bar{E}$ represents the decision fuzzy matrix having variables $B$ and criteria $D$, which is shown in the linguistic values in table 11.

Step 5.2: Normalize the decision matrix, which is to be calculated as:

$$
\begin{aligned}
& \overline{\mathrm{U}}=\overline{(\mathrm{u}})_{\mathrm{a}^{* \mathrm{~b}},}, \quad I=1,2, \ldots \ldots \ldots . . \mathrm{a}: \quad \mathrm{j}=1,2, \ldots \ldots \ldots . . \mathrm{b}, \\
& \overline{\mathrm{r}_{\mathrm{ij}}}=\left[\begin{array}{lll}
\mathrm{P}_{\mathrm{ij}} & \mathrm{q}_{\mathrm{ij}} & \mathrm{q}_{\mathrm{ij}} \\
---, & ---, & --- \\
\mathrm{D}_{\mathrm{j}} & \mathrm{D}_{\mathrm{j}} & \mathrm{D}_{\mathrm{j}}
\end{array}\right]
\end{aligned}
$$

Where $D_{j}=\max$ of $D_{i j}$. To solve these complicated 
TOPSIS normalization calculation, the simpler scale calculation method is used. Many researchers was also applied these techniques to solve linear scale transformation followed by normalization. The value of $D_{i j}=1$, because normalized decision matrix is always remains same.

Step 5.3: calculate the weighted matrix for the decision. Next point is to calculate the normalized weighted decision fuzzy matrix which is shown by table 12 .

$\overline{\mathrm{O}}_{\mathrm{ij}}=\overline{\mathrm{U}}_{\mathrm{ij}} * \overline{\mathrm{W}}_{\mathrm{kj}}$

Where $W_{k j}$ is the value of weight obtained by supermatrix for criteria $\mathrm{J}$.

And $\overline{\mathrm{V}}=\left(\overline{\mathrm{V}}_{\mathrm{ij}}\right)_{\mathrm{a} * \mathrm{~b}}, \mathrm{i}=1,2, \ldots \ldots \ldots \mathrm{a}, \quad \mathrm{j}=1,2, \ldots \ldots \ldots \ldots . \mathrm{b}$

Step 5.4: Find out the differences from the positive and negative real values.

The real triangular fuzzy points are in between $(0,1)$, so the positive and negative real points (FPIRP, FNIRP) are as follows:

$\mathrm{B}^{+}=\quad\left[\mathrm{O}_{1}^{+}, \quad \mathrm{O}_{2}^{+}, \ldots \mathrm{O}_{\mathrm{n}}^{+}\right], \quad \mathrm{B}^{--}=\left[\mathrm{O}_{1}^{--}\right.$, $\left.\mathrm{O}_{2}^{--}, \ldots \ldots \ldots \ldots \ldots \mathrm{O}_{\mathrm{n}}^{--}\right]$

Where $\mathrm{O}_{\mathrm{n}}{ }^{+}=(1,1,1), \quad \mathrm{O}_{\mathrm{n}}{ }^{--}=(0,0,0) \ldots \ldots \ldots \ldots 11$

Then we should find out the distance of the opponents from FPIRP \& FNIRP.

$$
\mathrm{e}_{\mathrm{i}}^{+}=\sum_{\mathrm{i}=1}^{N} \mathrm{e}\left(\overline{\mathrm{O}}_{\mathrm{ij}}, \mathrm{O}_{\mathrm{j}}^{+}\right), \quad \mathrm{i}=1,2, \ldots \mathrm{a}, \mathrm{j}=
$$

$1,2, \ldots \ldots b \ldots 12$.

$$
\mathrm{e}_{\mathrm{i}}^{-}=\sum_{i=1}^{N} \mathrm{e}\left(\overline{\mathrm{O}}_{\mathrm{ij}}, \mathrm{O}_{\mathrm{j}}^{-}\right), \quad \mathrm{i}=1,2, \ldots \ldots \ldots \mathrm{a}, \mathrm{j}
$$

$$
=1,2, \ldots \ldots \ldots b \ldots \ldots \ldots \ldots . . . . . . .13 .
$$

$\mathrm{e}(\mathrm{G}, \mathrm{H})=\sqrt{ } 1 / 3\left[\left(\mathrm{~g}_{1}-\mathrm{h}_{1}\right)+\left(\mathrm{g}_{2}-\mathrm{h}_{2}\right)+\left(\mathrm{g}_{3}-\mathrm{h}_{3}\right)\right]$.

The value of negative distances and positive distances for the low carbon supplier opponents are shown in table 13.

Step 5.5: Show the ranking of all the opponents. Compute the attainments indices of the rank. The table 14 shows all the performance attainments of the applied hypothesis choose the best strategy from all. The highest value of performance index shows the best result which is T3 with score of 0.2350 .

\section{Managerial implications}

The present study has two important purposes, which includes some implications for decision makers \& purchasing officers in which the evaluation of suppliers is measured for their sustainability. The first main purpose involves the construction of list of examination criteria with the help of literature survey and the second purpose is the development of MCDM technique for supplier selection. Build up the examination criteria for concern suppliers and calculate the relative importance, which makes the study better understandable by the managers. In these study criteria for LCSCM practices are identified. All these factors are compared with the previously applied hypothesis for identifying the target supplier. It can help to make the full concern on the targeted area of each manufacturing industry. In this uncertain environment, an improved hypothesis is developed. By using this approach, ranking of all suppliers have done. By using all three methods, managers can identify the effective one. The results of the study are cost reduction, pollution control by LCSCM, Product quality improvement, social benefits etc, which are helpful for industry to achieve goal.

\section{Conclusions}

On getting the adverse effect of globalization process, industries should consider and adopt some preventive measures for the protection of earth against these hazards issues such as carbon emission, pollutive environment, ethical issue, global issues and adverse health condition. In low carbon supply chain management point of view, industries are own responsible for global and environmental decay because of their profitability nature. The primary aim of LCSCM is to maintain all parameters to regain, enhance, and generate carbon free environment and for the economical \& social benefits. It is known by all industrialists that supplier selection is very important parameter. LCSCM process begins from the selection of raw material or service and followed by utilization of this product or service by the consumer. The effective utilization of low carbon supply chain management in an industry depends upon their performance \& supplier selection criteria. Industries should maintain a strong relationship with their suppliers \& to motivate them to make good quality product and to deliver on time. In LCSCM process the supplier selection is followed a systematic approach. Industries needs to take some preventive measures against the suppliers which have their poor performance. The manufacturing industry is one of the serious industries in India from where environmental pollution level is high. The LCSCM supplier selection problem has been already discussed in many previous literature. Also a few literature defines the analyzing part of low carbon supplier selection problems. For that particular point, this research become important to share with a industry of manufacturing sector which analyze the low carbon supplier selection methodology. The main and the critical portion the low carbon supplier selection operation is the determination of the key indicators of performance to choose extremely important supplier. The appropriate supplier selection strategy helps industries to achieve their goals. The applied supplier selection strategy should be genuine, transparent, easy to understand and logic based. The present study based on the questionnaire review as well as the industrial \& institutional experts suggestions. So the 
applied study measured on manufacturing industry is clearly verified \& specially focused on LCSC supplier selection problem. The combined fuzzy DEMATEL-ANP-TOPSIS technique is applied to investigate the most appropriate supplier which shows their greatest performance index value. In order to verify the originality of the present methodology, a fundamental case study is developed in an Indian manufacturing industry. This combined fuzzy DEMATEL-ANP-TOPSIS approach gives the most appropriate analysis result between these set of variables. In this study fuzzy TOPSIS tool is used to evaluate the real solution of the given problem. By applying these three set of tools each parts of the criteria is to be discussed and shown separately by using tabular form. With the help of above hypothesis, it can concluded that the novel hybrid MCDM approach to evaluate low carbon supplier to the improvement of LCSCM alternatives is the one which have greater final performance index having value of 0.2350 with corresponding index of supplier (T3) is the best criteria in this method. Previously many researchers proposed their models using these three set of tools. Overall the above research model proposes a best result of many MCDM problems.

\section{Declaration of conflicting interest}

The author(s) declared no conflicts of interest for the research, authorship, and/or publication of this article.

\section{Acknowledgement}

We are thankful to the Mechanical Engineering Department, Sant Longowal Institute of Engineering \& Technology, Sangrur, Punjab, for their valuable guidance and numerous companies related to production \& manufacturing background for sharing the valuable details of their personal data. We are also thankful to editors, reviewers and all the connected members for their beneficial guidance.

\section{References}

1) Odeyale, Solomon \& Oguntola, Alamu \& Odeyale, Elizabeth. (2014). Evaluation and selection of an effective green supply chain management strategy: A case study. International Journal of Research Studies in Management. 3. 10.5861/ijrsm.2013.550.

2) Tahriri, Farzad \& Dabbagh, Mohammad \& Ale Ebrahim, Nader. (2014). Supplier Assessment and Selection Using Fuzzy Analytic Hierarchy Process in a Steel Manufacturing Company. Journal of Scientific Research and Reports. 3. 1319-1338. 10.6084/M9.FIGSHARE.1008767.

3) Lupo, T. (2016). A fuzzy framework to evaluate service quality in the healthcare industry: An empirical case of public hospital service evaluation in Sicily. Applied Soft Computing, 40, 468-478. doi:10.1016/j.asoc.2015.12.010.

4) Ali Asghar Anvary Rostamy , Vahid Baghaei , Farideh Bakhshi Takanlou, Amin Anvary Rostamy . "A Fuzzy Statistical Expert System for Cash Flow Analysis and Management under Uncertainty." Advances in Economics and Business 1.2 (2013) 89 102. doi: 10.13189/aeb.2013.010205.

5) Shaverdi, M., Ramezani, I., Tahmasebi, R., \& Rostamy, A. A. A. (2016). Combining Fuzzy AHP and Fuzzy TOPSIS with Financial Ratios to Design a Novel Performance Evaluation Model. International Journal of Fuzzy Systems, 18(2), 248-262. doi:10.1007/s40815-016-0142-8

6) Adelina, W., \& Kusumastuti, R. D. (2017). Green supply chain management strategy selection using analytic network process: case study at PT XYZ. IOP Conference Series: Materials Science and Engineering, 166, 012026. doi:10.1088/1757-899x/166/1/012026

7) Ashrafzadeh, Maysam \& Mokhatab rafiei, Farimah \& Mollaverdi, Naser \& Zare, Zahra. (2012). Application of fuzzy TOPSIS method for the selection of Warehouse Location: A Case Study. Interdiscipl J Contemp Res Business. 3.

8) Kabir, G., \& Hasin, M. A. A. (2013). Integrating modified Delphi method with fuzzy AHP for optimal power substation location selection. International Journal of Multicriteria Decision Making, 3(4), 381. doi:10.1504/ijmcdm.2013.056654

9) Tang, Y. C., \& Beynon, M. J. (2009). Group decision-making within capital investment: a Fuzzy Analytic Hierarchy Process approach with developments. International Journal of Operational Research, 4(1), 75. doi:10.1504/ijor.2009.021619

10) Uygun, Ö., \& Dede, A. (2016). Performance evaluation of green supply chain management using integrated fuzzy multi-criteria decision making techniques. Computers \& Industrial Engineering, 102, 502-511. doi:10.1016/j.cie.2016.02.020

11) Kuo, R. J., Hsu, C. W., \& Chen, Y. L. (2015). Integration of fuzzy ANP and fuzzy TOPSIS for evaluating carbon performance of suppliers. International Journal of Environmental Science and Technology, 3863-3876. doi:10.1007/s13762-015-0819-9

12) Büyüközkan, G., \& Çifçi, G. (2012). A novel hybrid MCDM approach based on fuzzy DEMATEL, fuzzy ANP and fuzzy TOPSIS to evaluate green suppliers. Expert Systems with Applications, 39(3), 3000-3011. doi:10.1016/j.eswa.2011.08.162

13) Ahmed Khan, S., Kusi-Sarpong, S., Kow Arhin, F., \& Kusi-Sarpong, H. (2018). Supplier sustainability performance evaluation and selection: A framework and methodology. Journal of Cleaner Production. doi:10.1016/j.jclepro.2018.09.144 
14) Mohammed, A. (2019). Towards a sustainable assessment of suppliers: an integrated fuzzy TOPSIS-possibilistic multi-objective approach. Annals of Operations Research. doi:10.1007/s10479-019-03167-5

15) Pang, Q., Yang, T., Li, M., \& Shen, Y. (2017). A Fuzzy-Grey Multicriteria Decision Making Approach for Green Supplier Selection in Low-Carbon Supply Chain. Mathematical Problems in Engineering, 2017, 1-9. doi:10.1155/2017/9653261

16) Fahimeh Aliakbari Nouri, Saber Khalili Esbouei, Jurgita Antucheviciene, A Hybrid MCDM Approach Based on Fuzzy ANP and Fuzzy TOPSIS for Technology Selection, Informatica 26(2015), no. 3, 369-388, DOI 10.15388/Informatica.2015.53.

17) Aiello, G. (2009). Clean agent selection approached by fuzzy TOPSIS decision making method. Fire Technology, 45, 405-418.

18) X. Liu, Z. Tao, H. Chen, and L. Zhou, "A new interval-valued2-tuple linguistic bonferroni mean operator and its app-lication to multi-attribute group decision making,"International Journal of Fuzzy Systems, vol. 19, no. 1,pp. 86-108, 2017.

19) Amiri, M., Zandieh, M., Soltani, R., \& Vahdani, B. (2009). A hybrid multi-criteria decision-making model for firm's competence evaluation. Expert Systems with Applications, 36, 12314-12322.

20) Huzaifi, Muhammad \& Budiyanto, Arif \& Sirait, Juanda. (2020). Study on the Carbon Emission Evaluation in a Container Port Based on Energy Consumption Data. Evergreen. 7. 97-103. 10.5109/2740964.

21) T. Fujisaki, "Evaluation of green paradox: case study of japan,” Evergreen, 5 (4) 26-31 (2018). doi:10.5109/2174855.

22) H. Han, M. Hatta, and H. Rahman, "Smart ventilation for energy conservation in buildings," Evergreen, 6 (1) 44-51 (2019).

23) A. Pal, K. Uddin, K. Thu, and B.B. Saha, Evergreen, 5 (2), 58-66 (2018).

24) Yusei Masaki. Evergreen Joint Journal of Novel Carbon Resources Sciences \& Green Asia Strategy, Vol. 03, Issue 02, pp. 59-67, September (2016)

25) Masahito Tanaka. Evergreen Joint Journal of Novel Carbon Resources Sciences \& Green Asia Strategy, Vol. 04, Issue 04, pp. 1-7, December (2017)

26) Chen, S. J., \& Hwang, C. L. (1992). Fuzzy multiple attribute decision-making methods and application. In Lecture notes in economics and mathematical systems. New York: Springer.

27) Chen-Yi, H., Ke-Ting, C., \& Gwo-Hshiung, T. (2007). FMCDM with fuzzy DEMATEL approach for customers' choice behavior model. International Journal of Fuzzy Systems, 9(4), 236-246.

28) Kumar, M., Vrat, P., \& Shankar, R. (2006). A fuzzy goal programming approach for vendor selection problem in a supply chain. International Journal of Production Economics, 101, 273-285..

29) Lin, R.-H. (2009). An integrated FANP-MOLP for supplier evaluation and order allocation. Applied Mathematical Modelling, 33, 2730-2736.

30) Liou, J. J. H., Yen, L., \& Tzeng, G.-H. (2008). Building an effective safety management system for airlines. Journal of Air Transport Management, 14(1), 20-26.

31) Liu, K. F. R., \& Lai, J.-H. (2009). Decision-support for environmental impact assessment: A hybrid approach using fuzzy logic and fuzzy analytic network process. Expert Systems with Applications, 36, 5119-5136.

32) Bhasin, Niti \& Kar, Rabi \& Arora, Neha. (2015). Green Disclosure Practices in India: A Study of Select Companies. Evergreen. 2. 5-13. 10.5109/1544075.

33) Luo, Z.-M., Zhou, J.-Z., Zheng, L.-P., Mo, L., \& He, Y.-Y. (2010). A TFN-ANP based approach to evaluate Virtual Research Center comprehensive performance. Expert Systems with Applications, 37(12), 8379-8386.

34) Mohanty, R. P., Agarwal, R., Choudhury, A. K., \& Tiwari, M. K. (2005). A fuzzy ANP based approach to R\&D project selection: A case study. International Journal of Production Research, 43, 5199-5216.

35) Punniyamoorthy, M., Mathiyalagan, P., \& Parthiban, P. (2011). A strategic model using structural equation modeling and fuzzy logic in supplier selection. Expert Systems with Applications, 38(1), 458-474.

36) Ramik, J. (2007). A decision system using ANP and fuzzy inputs. International Journal of Innovative Computing, Information and Control, 3(4), 825-837.

37) Roghanian, E., Rahimi, J., \& Ansari, A. (2010). Comparison of first aggregation and last aggregation in fuzzy group TOPSIS. Applied Mathematical Modelling, 34(12), 3754-3766.

38) Saaty, T. L. (1996). The analytic network process. Pittsburgh: RWS Publications. 